\title{
Main faults of the Betic Cordillera
}

\author{
Carlos Sanz de Galdeano \\ Instituto Andaluz de Ciencias de laTierra (CSIC-Univ. Granada). 18071. Granada, Spain. \\ csanz@ugr.es
}

\begin{abstract}
In the Betic Cordillera the faults correspond to thrusts forming tectonic units and to three important sets of vertical or quasi-vertical faults. In the Internal Zone the thrusts formed mainly during the Oligocene, under an approximately N-S compression. Later, in the Burdigalian, the Internal Zone collided with the External Zone, which underwent major deformations. Then $\mathrm{N} 60^{\circ} \mathrm{E}-\mathrm{S} 60^{\circ} \mathrm{W}$ to $\mathrm{E}-\mathrm{W}$ dextral strike-slip faults formed. These faults formed under nearly E-W compression. From the end of the middle Miocene, the near N-S compression was reestablished and then formed two conjugated sets of faults whose directions are: NNE-SSW (with sinistral character) and NNW-SSE to NW-SE (with dextral character). Not only are the aforementioned major faults, but the rocks also have many other small faults and joints that formed under the same stresses.
\end{abstract}

Keywords: Betic Cordillera, fractures, faults, joints.

\section{Principales fallas de la Cordillera Bética}

\section{RESUMEN}

En la Cordillera Bética las fallas corresponden a los cabalgamientos que formaron las unidades tectónicas y a tres importantes juegos de fallas verticales o casi verticales. En la Zona Interna los cabalgamientos se formaron en general durante el Oligoceno, bajo una compresión aproximadamente N-S. Más tarde, en el Burdigaliense, la Zona Interna colisionó con la Externa, la cual sufrió importantes deformaciones. Entonces se formaron fallas de dirección $\mathrm{N} 60^{\circ} \mathrm{E}-\mathrm{S} 60^{\circ} \mathrm{O}$ a $\mathrm{E}-\mathrm{O}$ con carácter de desgarre dextrorso, bajo una compresión aproximada E-O. Desde el final del Mioceno medio, la compresión N-S se restableció y se formaron dos nuevos juegos de fallas cuyas direcciones son NNE-SSO (de carácter sinistrorso) y NNO-SSE a NO-SE (de carácter dextrorso). No solo existen esas importantes fracturas sino también un sinnúmero de otras menores (diaclasas y pequeñas fallas) presentes en el conjunto de las rocas y formadas bajo los mismos esfuerzos.

Palabras clave: Cordillera Bética, fracturas, fallas, diaclasas. 


\section{VERSIÓN ABREVIADA EN CASTELLANO}

\section{Introducción}

La Cordillera Bética (Figs. 1 y 2), en la que se distinguen fundamentalmente sus zonas Interna y Externa, ha desarrollado durante su proceso de estructuración varios y bien definidos juegos de fallas. Esta estructuración se hizo en varias etapas, que van desde fundamentalmente el Oligoceno al presente. Este artículo intenta dar una panorámica de esta fracturación, indicando esos juegos de fallas y su relación con las etapas de estructuración. También se dan algunas ideas sobre las relaciones existentes entre las grandes y pequeñas fracturas.

\section{Las fallas en la Cordillera Bética}

Corresponden a dos tipos principales: los cabalgamientos que formaron las unidades tectónicas, y fallas verticales o de gran buzamiento. Estas últimas se pueden agrupar en tres juegos principales (Fig. 3) cuyas direcciones son: 1) N60 ${ }^{\circ} E-N 600$ a E-O, 2) NNE-SSO y 3) NNO-SSE a NO-SE (Sanz de Galdeano, 1983). Los juegos 2 y 3 son conjugados y forman un sistema de fallas.

Los cabalgamientos: son generalmente de bajo ángulo y separan las unidades tectónicas. En la Zona Interna se formaron sobre todo durante el Oligoceno, mientras que en la Externa lo hicieron posteriormente, a partir del Burdigaliense, por la colisión oblicua de la Zona Interna que fue expulsada hacia el oeste por causa de la apertura de la cuenca Argelo-Provenzal.

El juego de fallas $N 60^{\circ} \mathrm{E}-\mathrm{N} 600$ a $\mathrm{E}-\mathrm{O}$. A este juego corresponden varias fallas muy importantes:

El contacto entre las zonas Interna y Externa. Debido a la citada colisión se formó el contacto entre ambas zonas que es la fractura más importante de la Cordillera y tiene una dirección media $N 65^{\circ} \mathrm{E}-\mathrm{S} 65^{\circ} \mathrm{O}$. Este contacto quedó progresivamente paralizado a la vez que se formaron otras fallas, más o menos paralelas, al $N$ y al $S$ del mismo y que se indican a continuación. Todas ellas contribuyeron a facilitar la traslación de la Zona Interna hacia el oeste.

La falla Cádiz-Alicante. Es prácticamente paralela a la anterior y se observa bien sobre todo en su parte oriental. Hacia el oeste se observa peor, sobre todo en la zona de Cádiz donde en muchos puntos no es visible.

Los corredores E-O dentro de la Zona Interna. Corresponden a fallas E-O de carácter dextrorso cuyos movimientos han dado lugar a corredores topográficos. De los tres existentes el más importante es el de las Alpujarras. Está formado por fallas dextrorsas, aunque algunas de ellas presentan importantes movimientos verticales.

El sistema formado por los juegos de fallas NNE-SSO a NE-SO y NNO-SSE a NO-SE.

La Zona de Cizalla Oriental Bética. Corresponde a numerosas fallas sinistrorsas NNE-SSO, que en su conjunto determinan una importante línea de fracturas. Se extiende desde Murcia a Almería e incluso pasa al mar de Alborán. Separan dos dominios de muy diferente espesor cortical, más grueso en el lado oeste.

El juego de fallas NNO-SSE. Se distribuye por toda la Cordillera, destacando las del borde oriental de la cuenca de Granada. Generalmente son dextrorsas, aunque muchas de ellas presentan también importantes movimientos verticales.

\section{Principales rasgos de la sismicidad y de las fallas activas}

Las Béticas presentan una sismicidad activa aunque moderada. Su distribución general puede verse en la Fig. 4. La mayoría de los terremotos son superficiales, aunque hay algunos profundos y otros intermedios (Fig. 5) que dibujan una disposición en arco, presumiblemente la zona de subducción propuesta por Pedrera et al (2011).

De modo muy resumido se presentan las fallas activas de la Cordillera (Fig. 6), (de las cuales existe un catálogo, García Mayordomo et al., 2012) y los mecanismos focales de terremotos que muestran diversos movimientos (Fig. 7).

\section{Edad, condiciones geodinámicas y redes de fracturas relacionadas}

Las primeras fallas formadas fueron los cabalgamientos de las unidades tectónicas, los cuales se produjeron bajo una compresión aproximadamente $\mathrm{N}-\mathrm{S}$. 
El contacto de la Zona Interna con la externa ocurrió aproximadamente durante el Burdigaliense. Inmediatamente se formó la zona de fallas de Cádiz-Alicante y los corredores E-W situados en la Zona Interna. Estas fallas se formaron bajo una compresión E-O debida a la apertura de la cuenca Argelo-Provenzal, prolongada hacia el mar de Alborán. Posteriormente, cuando ese proceso perdió importancia se restableció la compresión aproximada N-S y se formó la gran Zona de Cizalla Bética oriental y las fallas conjugadas NNO-SSE. Debido a las diferentes situaciones geodinámicas muchas fallas han tenido diferentes tipos de desplazamiento.

Fallas menores y diaclasas asociadas a las grandes fallas.

También se han desarrollado gran número de fallas de menor importancia, incluyendo diaclasas. Naturalmente, junto a las grandes fallas existen redes de fracturas más pequeñas, pero también se han formado lejos de esas grandes fallas, afectando al conjunto de las rocas. Esto puede verse en numerosos lugares, así en los complejos Nevado-Filábride y Alpujárride en los que existen infinitas diaclasas de dirección NE-SO y sus conjugadas NO-SE (Sanz de Galdeano et al., 1984 y 1985a \& b, Almécija et al. (1996)) (Fig. 8). También existen numerosas fracturas menores relacionadas con el plegamiento.

Se ha podido establecer una cierta relación entre los principales juegos de fallas y las direcciones de karstificación y también con el termalismo (Benavente and Sanz de Galdeano, 1985) siendo las fallas de dirección NO-SE a NNO-SSE las que mayor control ejercen.

\section{A modo de conclusión}

En la Cordillera Bética las fallas corresponden a cabalgamientos entre unidades tectónicas y a importantes juegos de fallas verticales o de gran ángulo. Los cabalgamientos se formaron en general en primer lugar. Posteriormente, con la deriva de la Zona Interna hacia el oeste se formó el contacto con la Externa y otras fallas que ayudaron a este movimiento. Esto último ocurrió desde el Burdigaliense. A partir del Mioceno medio, nuevamente con una compresión aproximadamente $\mathrm{N}-\mathrm{S}$, junto con una extensión aproximadamente perpendicular, se formaron los dos juegos de fallas conjugados NNE-SSO y NNO-SSE.

Los anteriores juegos de fallas están también presentes a pequeña escala siendo numerosísimas las fallas y diaclasas que afectan las rocas, de una forma casi penetrativa.

\section{Introduction}

The Betic Cordillera, together with the Rif, is situated in the westernmost part of the Mediterranean Sea (Fig. 1). In it several well-defined sets of faults have developed during the process of its structuring. Some of these faults correspond to the thrust surfaces of the different tectonic units of the cordillera, which were affected by later faults, then disorganizing part of the previous structuration. These great fractures are accompanied by infinite small faults and joints.

The purpose of this paper is to present an overview of the fracturing of the Betic Cordillera, indicating the main sets in which they are distributed and the geodynamic factors forming them, and also to give some idea of the existing relationships amongst the main and the smaller fractures.

\section{Regional setting}

The Betic Cordillera, more or less $600 \mathrm{~km}$ long and $200 \mathrm{~km}$ wide, is divided into Internal and External Zones (Fig. 2) in addition to other domains, including the Flysch Units (mainly present in the area of Gibraltar) and the Neogene basins (Durand-Delga and Fontboté, 1980; Vera (2001).

The Internal Zone is formed by three tectonically superposed complexes, which from bottom to top are the Nevado-Filabride, Alpujarride, and Malaguide complexes.

The Alpujarride and the Nevado-Filabride complexes were affected by Alpine metamorphism. They present mainly Paleozoic and Triassic formations, with thick masses of marble. The Alpujarride Complex is structured in many superposed tectonic units that are mainly distributed into three groups (Aldaya et al. 1979). The division of the Nevado-Filabride Complex into units is a topic of debate. For many authors it is divided into several tectonic units (Augier et al., 2005), and even into two different complexes (Puga et al., 2002), but others consider that these divisions are not real (Galindo-Zaldívar, 1993; Sanz de Galdeano and López Garrido, 2016).

The Malaguide Complex is made up mainly of Paleozoic formations, and locally its Mesozoic and Tertiary cover remains. It is not affected by Alpine metamorphism. Linked to this complex is the Dorsal domain, 


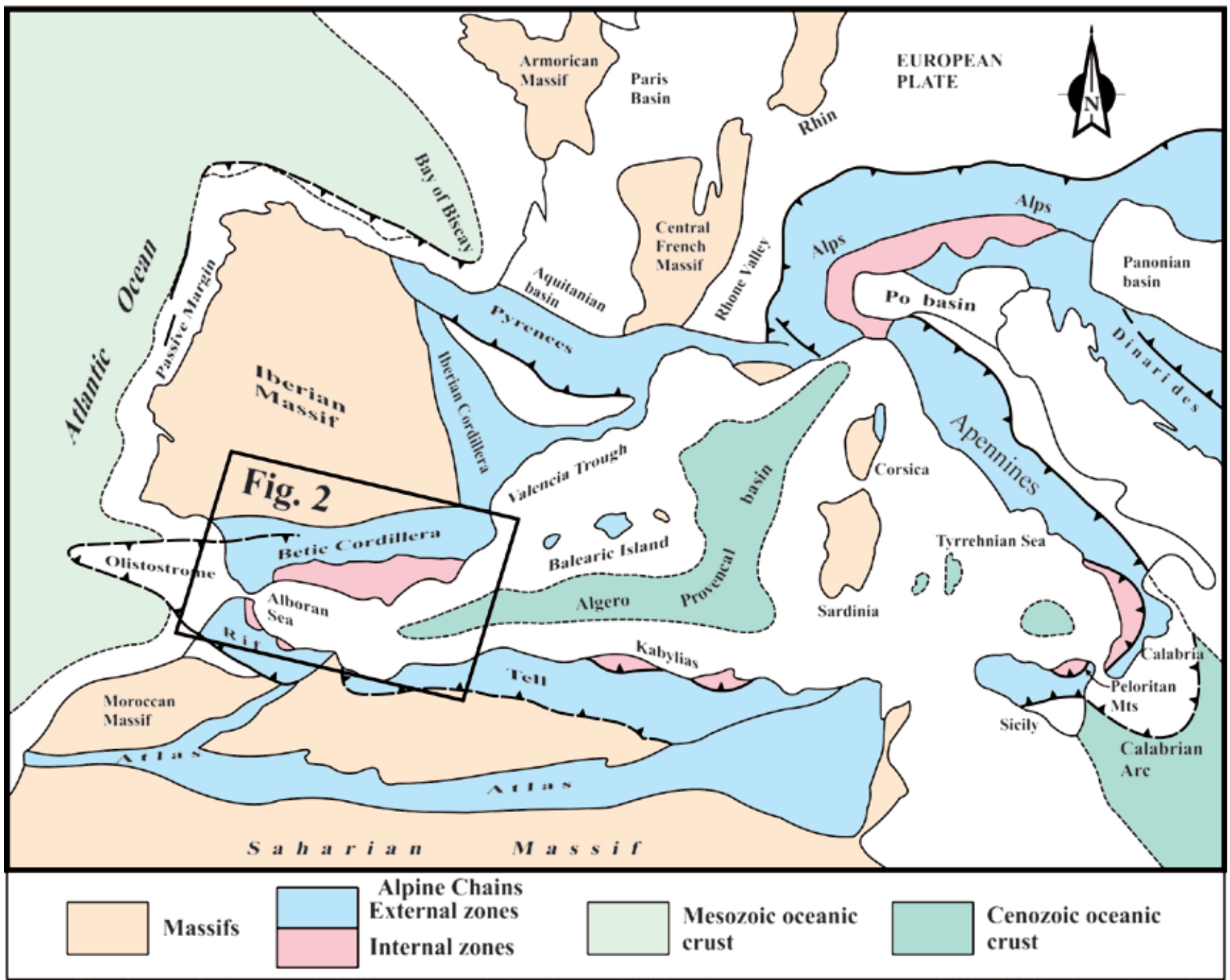

Figure 1. Regional geologic scheme of the western Mediterranean area, in which western end the Betics and the Rif are situated. The location of Figure 2 is indicated in the rectangle.

Figura 1. Esquema geológico regional del Mediterráneo occidental al oeste de la cual se sitúan las Béticas y el Rif. La posición de la figura 2 se indica en el rectángulo.

formed by Mesozoic and Tertiary sediments, situated in part over the Malaguide Complex and also in its southward and westward prolongation.

The External Zone, situated to the $\mathrm{N}$ of the Internal Zone, is divided in Prebetic and Subbetic. Both domains constituted the sedimentary Mesozoic and Tertiary cover of the S and SE prolongation of the Paleozoic Iberian Massif. Both domains present marine deposits, although in the Subbetic these are more pelagic in nature, whilst in the Prebetic the facies are shallower and even presenting some continental formations.

The Flysch Units are allochthonous tectonic units composed mainly of sedimentary Tertiary formations.
These units are present in southern Italy, traverse Algeria and Morocco, and in the Betics appear mainly in the western part. These units are tectonically superposed over the Internal and External Zones.

The Neogene basins are distributed along the entire cordillera (Fig. 2) and are synorogenic and posttectonic, according to their ages. All these basins were tectonically controlled during their formation and later evolution. The main one is the Guadalquivir Basin, which corresponds to a foreland basin and evolved during the middle Miocene to the present. The best conserved basins are those that formed from the late Miocene, as is the case of the Granada and Guadix-Ba- 


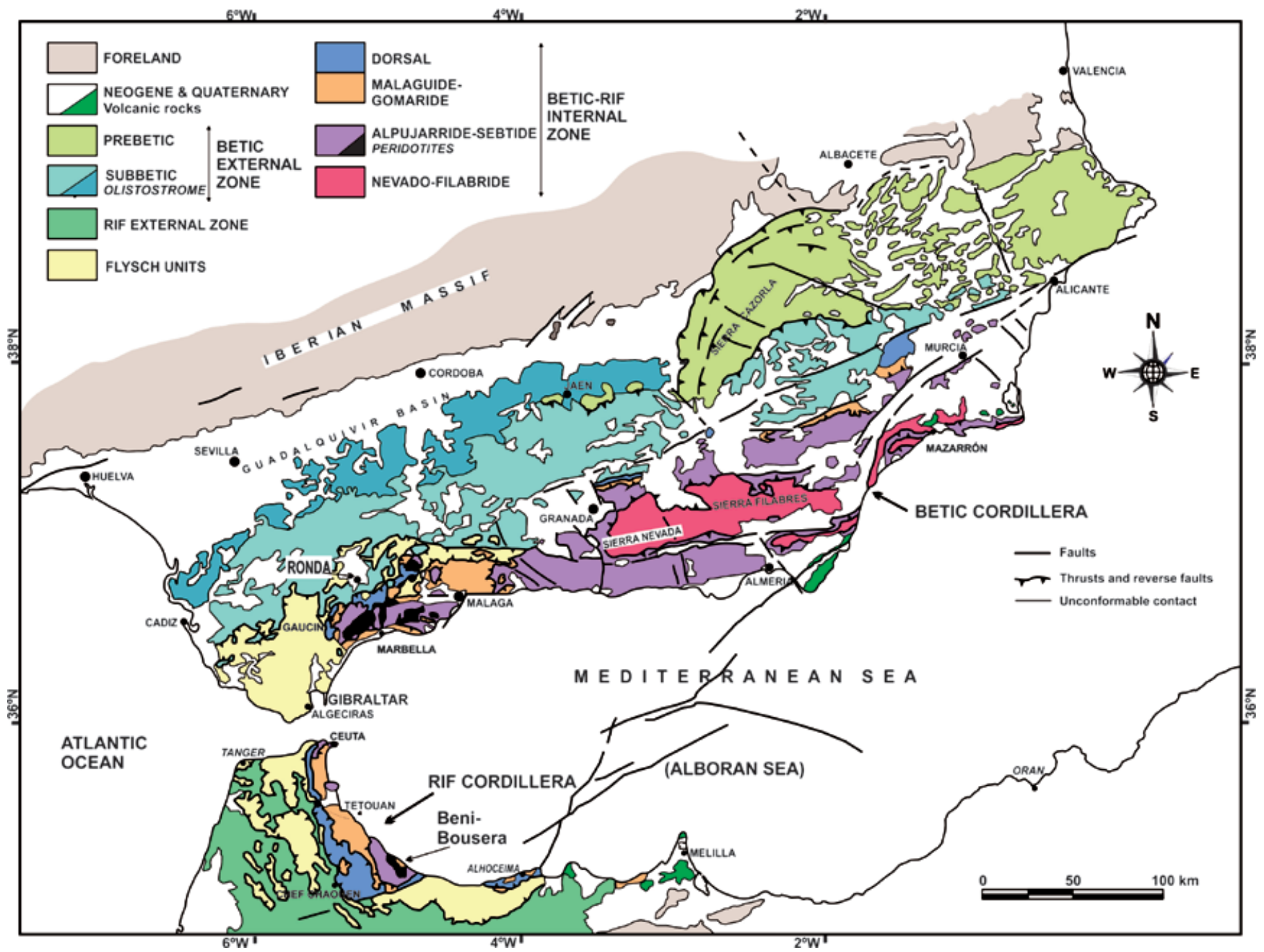

Figure 2. General geologic map of the Betic Cordillera and part of the Rif. The location is indicated in Figure 1.

Figura 2. Mapa geológico general de la Cordillera Bética y de parte del Rif. Su posición se indica en la Fig. 1.

za basins, amongst several other intramountain basins. These basins were formed over all of the previous domains.

The present structuring of the Betic Cordillera occurred throughout the Alpine Orogeny, particularly during the Eocene-Oligocene and early and middle Miocene. During this process, from the late Oligocene, the new Algero-Provençal basin began to open in the western Mediterranean Sea (Boillot et al., 1984, Sanz de Galdeano, 1990a) and extended to the west in the Alboran Sea, directly south of the Betic Cordillera. Because of this opening, the Betic-Rif Internal Zone (common to both cordilleras) was pushed westwards and coetaneously began to create a subduction zone forming the Gibraltar Arc, this still being active (Pedrera et al., 2011).

During the Burdigalian, the Internal Zone obliquely collided with the External Zone which then began to be deformed. Later, from the end of the middle Miocene to the present, the cordillera began to be uplifted (Sanz de Galdeano \& Alfaro, 2004) owing to a new N-S to NNW-SSE compression, linked to a practically orthogonal extension. At this time the great anticline of the Sierra Nevada was formed.

\section{The faults in the Betic Cordillera}

The faults of this cordillera correspond to the thrusts forming the tectonic units and to later vertical and high-angle fractures. The latter can be grouped into three important sets (Fig. 3), whose directions are: 1) $N 60^{\circ} \mathrm{E}-\mathrm{N} 60 \mathrm{~W}^{\circ}$ to $\mathrm{E}-\mathrm{W}$, 2) NNE-SSW, and 3) NNW-SSE to NW-SE (each case has some variations in strike) (Sanz de Galdeano, 1983). The latter two sets are conjugated and form a fault system. 


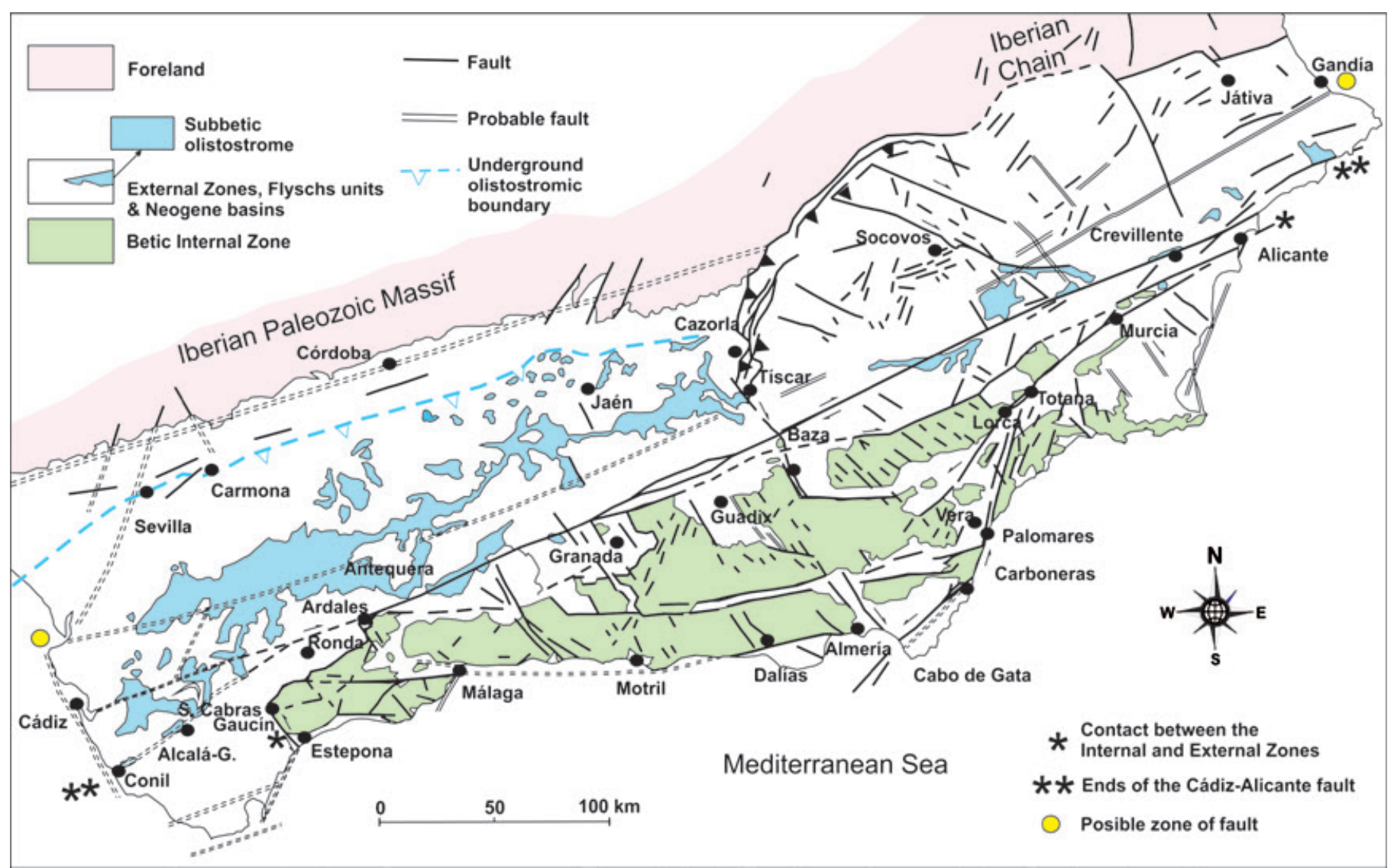

Figure 3. Simplified scheme of the main faults of the Betic Cordillera. Redrawn and slightly simplified from Sanz de Galdeano (1983).

Figura 3. Esquema simplificado de las principales fallas de la Cordillera Bética. Redibujado y ligeramente modificado de Sanz de Galdeano (1983).

\section{The thrusts.}

The thrusts of the tectonic units in the Betics, both in the Internal and External Zones, have generally reverse character and low angle. Part of these thrusts are indicated in Figure 2. The most important ones are those separating the tectonic complexes of the Internal Zone. Moreover, many other thrusts are situated between tectonic units within the Alpujarride Complex.

During the westward drift of the Internal Zone and particularly during the uplifting of the cordillera (mainly from the late Miocene), part of the previous tectonic contact shifted again, in some cases extensionally, and locally new low-angle faults formed. Also in the External Zone, mainly in the Subbetic, some later movements occurring from the end of the early Miocene took on olistostromic characteristics.

The $N 60^{\circ} \mathrm{E}-\mathrm{N} 60^{\circ} \mathrm{W}$ to $\mathrm{E}-\mathrm{W}$ set of faults.

This set is formed by several great faults:
The contact between the Internal and External Zones: This fault is the most important of the Betic Cordillera and all along its length the Internal Zone obliquely pushed the Subbetic. Although locally it has variable directions, on the whole its average strike is $\mathrm{N} 65^{\circ} \mathrm{E}-\mathrm{S} 65^{\circ} \mathrm{W}$. It has transcurrent dextral movements, although locally the reverse ones exist, with the Internal Zone well superimposed over the Subbetic, whilst in other places the Subbetic overlies the Internal Zone. However, overall, it has a more or less vertical dip.

This contact was progressively immobilized, although the tendency of the Internal Zone to move westwards continued. This caused new faults to appear, facilitating the westward displacements.

The Cádiz-Alicante faults: Approximately parallel to the contact between the Internal and the External Zones lies a line of faults called the Crevillente Fault in its eastern part (Foucault, 1974) or, considered over its entire length, the Cadiz-Alicante fault (Sanz de 


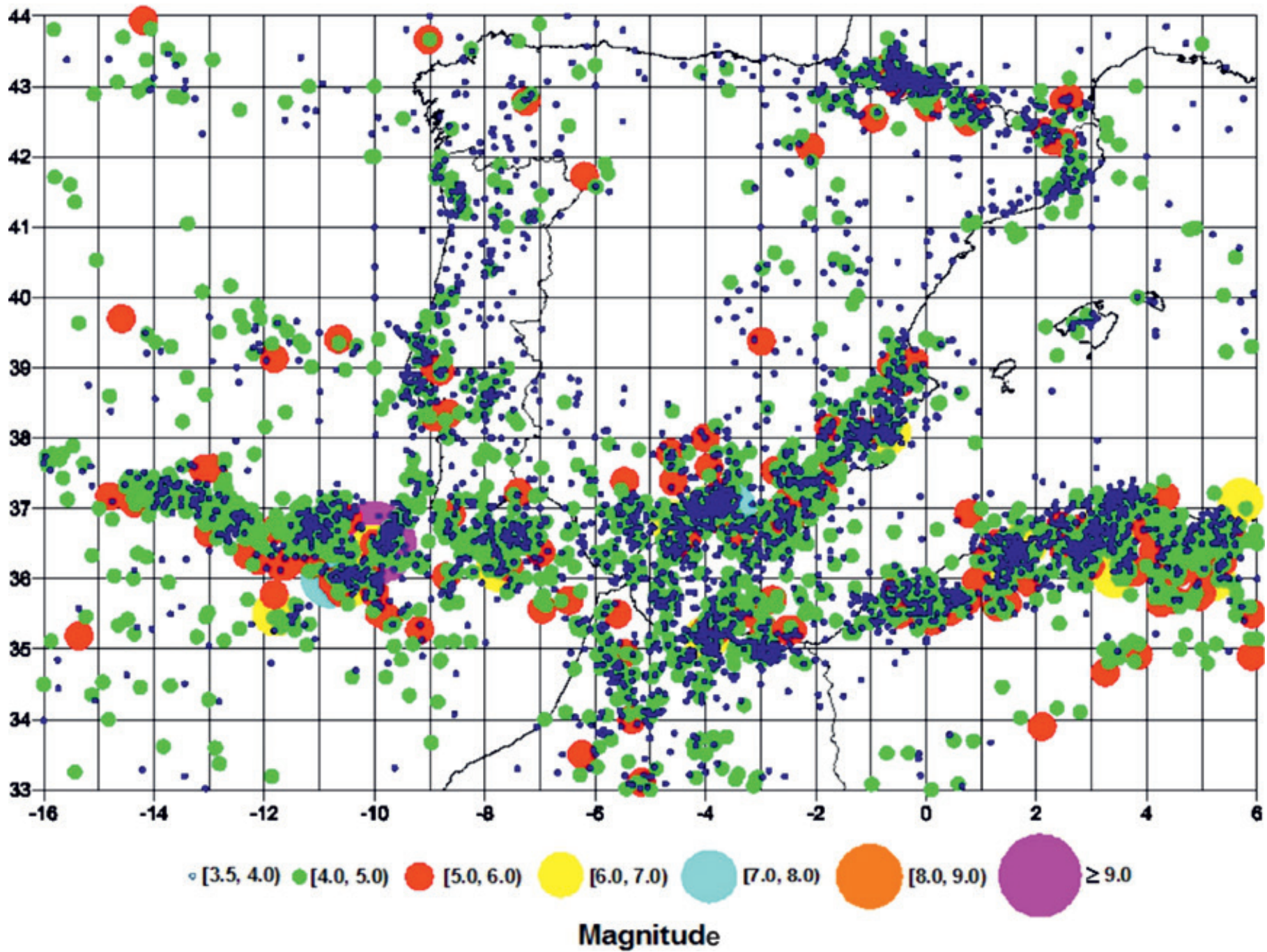

Figure 4. Earthquakes $(M>3.5)$ during the period 1400-2010 obtained from the update of the catalogue of the Instituto Geográfico Nacional (Mezcua and Martínez Solares, 1983; Martínez Solares and Mezcua, 2002). Taken from López-Casado and Henares Romero (2011).

Figura 4. Terremotos $(M>3.5)$ durante el periodo 1400-2010 obtenido de la actualización del catálogo del Instituto Geográfico Nacional (Mezcua y Martínez Solares, 1983; Martínez Solares y Mezcua, 2002). Tomado de López-Casado y Henares Romero (2011).

Galdeano, 1983, 2008). This fault line of $\mathrm{N} 60-70^{\circ} \mathrm{E}$ direction, overall dextral strike-slip in character, is clearly visible in its eastern part, in the provinces of Alicante and Murcia, whilst to the west, in the area of Cadiz, it is only very locally visible (in this sector the Subbetic olistostrome disorganizes previous structures, making it difficult to see them). In several sectors, two or more parallel fault lines appear.

The E-W corridors of the Internal Zone: Linked to the westward drift of the Internal Zone, several important E-W faults were formed within this zone, also dextral strike-slip in nature, at present corresponding to topographic corridors. The one located to the north is the Almanzora corridor, which separates the sierras Filabres and Estancias. Here, the main fault is situated on the south edge of the corridor, just on the northern border of the Sierra de los Filabres. To the east this corridor is displaced by the important NNE-SSW Eastern Betic Shear Zone described below.

Between the sierras Nevada and Filabres a line of E-W faults forms a depressed area (also coinciding with the synclinal zone situated between the two great anticlines forming each sierra). These faults are situated on the northern edge of the Sierra Nevada and can be followed from the south of the Guadix-Baza basin to the east, although their most eastern possible prolongation cannot be seen. The nature of these faults is not well known.

South of Sierra Nevada lies the best developed tectonic corridor of the cordillera. The main faults are sit- 


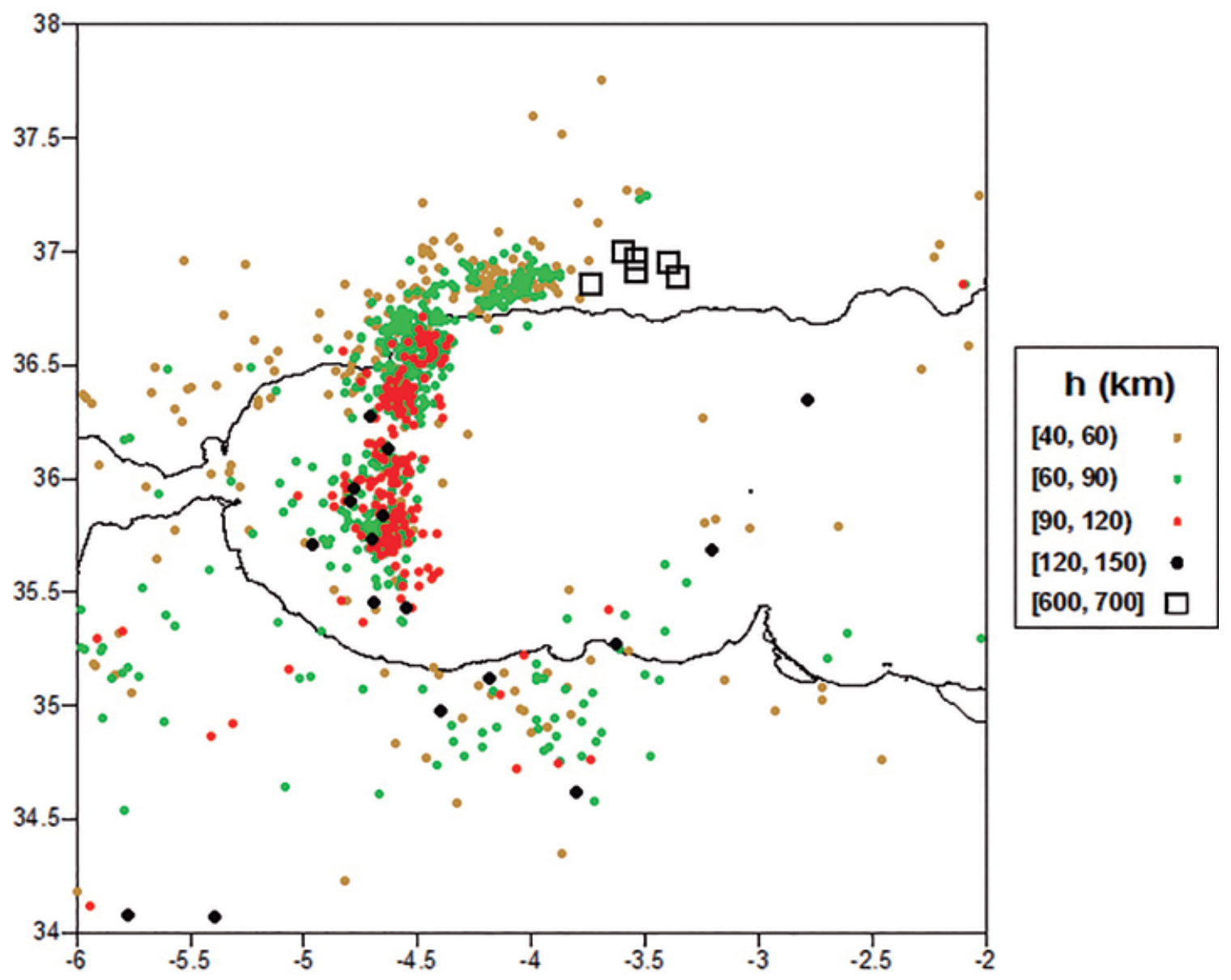

Figure 5. Intermediate and deep seismicity to the south of Granada and Malaga and in the Alboran Sea, from 1952 to 2011. Taken from López-Casado and Henares Romero (2011).

Figura 5. Sismicidad intermedia y profunda al sur de Granada y Málaga y en el Mar de Alborán, desde 1952 a 2011. Tomado de López-Casado y Henares Romero (2011).

uated just on the south border of Sierra Nevada, but others are situated parallel within and on the southern edge of the corridor. Their dextral strike-slip character is well identified (Sanz de Galdeano et al., 1985b; Martínez-Martínez, 2006), although some of these faults later present strong vertical movements.

Finally, the south coast of the Betic Cordillera has an E-W strike, suggesting the presence of faults of this direction. This strike continues to the west, in the Malaga Basin. But in the field these possible faults are not clearly identified, with the exception of some points of the Malaga Basin. This means that the existence of a generalized line of E-W faults in this position cannot be affirmed (the southern border is occupied by the sea), but at least an important flexure is situated there.

The system formed by the NNE-SSW to NE-SW and NNW-SSE to NW-SE sets of faults.
These two sets of faults, although conjugated, develop unequally as indicated below:

The Eastern Betic Shear Zone: This is formed by numerous NNE-SSW faults which on the whole constitute a unique shear zone. Undoubtedly, this is a major feature in the eastern part of the Betics (Bousquet, 1979; Martínez Díaz, 2002). In its northern part, these faults are situated near the city of Murcia, form the west border of the Sierra de Carrascoy and continue southward in the area of Palomares, Carboneras, and Gata (with faults of these names). Finally they cross the Alboran Sea (Hernández et al., 1987; Larouzière et al., 1988, Mauffret et al., 1992) to northern Morocco. Many of these faults present excellent outcrops and their sinistral strike-slip character is clearly visible.

On both sides of this shear zone the thickness of the crust is quite different, more or less $40 \mathrm{~km}$ on the 


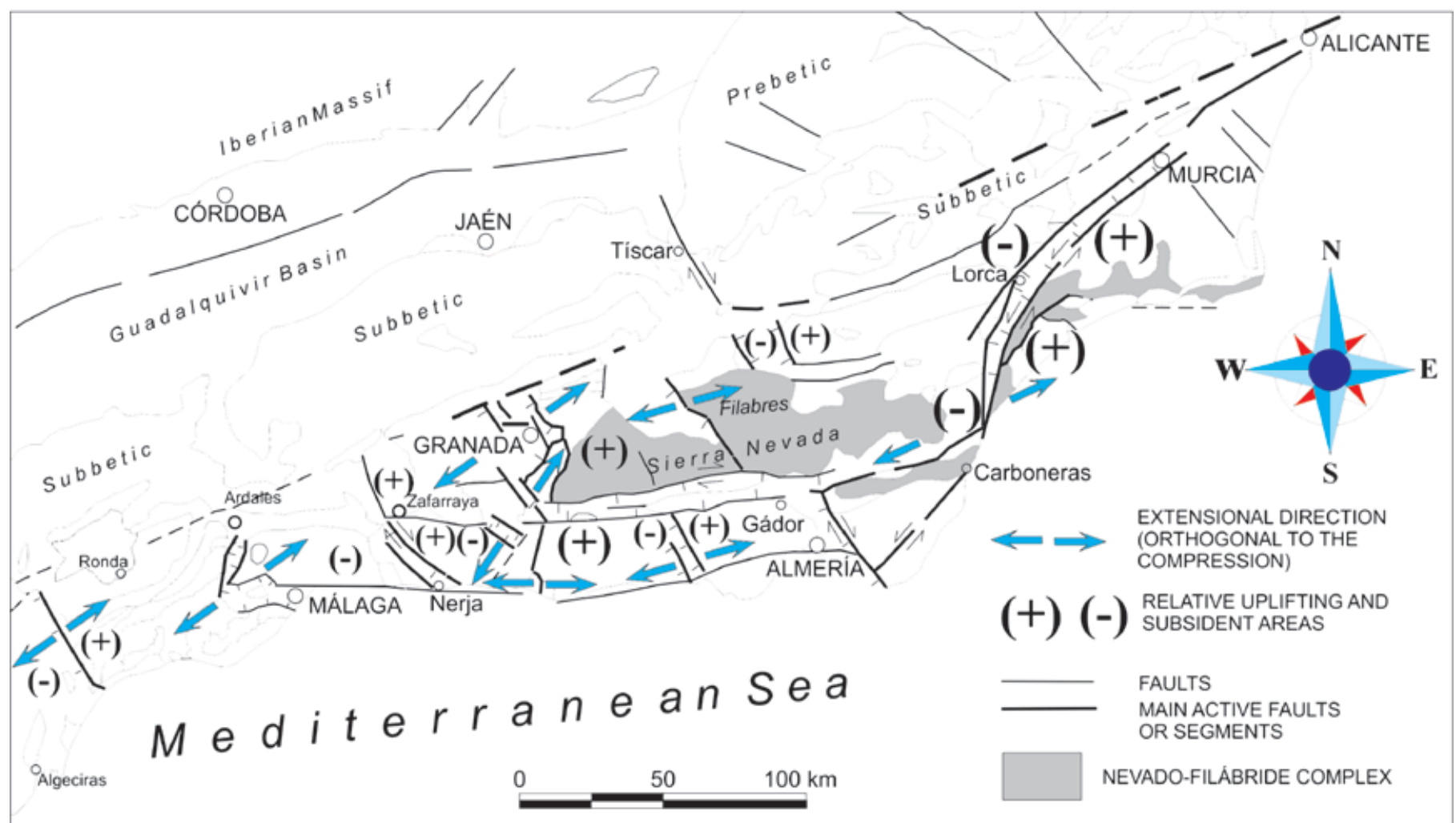

Figure 6. Simplified sketch of the Betic Cordillera indicating its neotectonic and active faults. The main areas of uplift and subsidence are indicated together with the directions of extension detected. Taken from Sanz de Galdeano and Peláez (2011).

Figura 6. Esquema muy simplificado de la Cordillera Bética en el que se indican sus fallas neotectónicas y activas. También se señalan las principales áreas de levantamiento y subsidencia y las direcciones de extensión detectadas. Tomada de Sanz de Galdeano y Peláez (2011).

western side and less than $30 \mathrm{~km}$, or even $20 \mathrm{~km}$, on the eastern side (Montenat et al., 1987; Larouzière et al., 1988). This gives an idea of the importance of these faults. In fact, they are only a part of the system of faults that from Northern Europe continue to the Atlas, controlling the Rhine and Rhone basins (Sanz de Galdeano, 1990b).

The NNW-SSE to NW-SE set of faults: These faults are distributed along the entire cordillera. From W to $E$, appear the Gaucín fault, the faults of the Nerja sector, those of the Granada Basin, and the Tíscar fault. The first, formed during the westward drift of the Internal Zone, is conjugated with the E-W faults and is sinistral in nature. The rest are mostly dextral and normal.

\section{Main features of the seismicity and active faults}

The Betic Cordillera presents active but moderate seismicity. The general distribution of this activity can be seen in Figure 4, which includes that of the surrounding region. Most of these earthquakes are superficial, but a few are deep and, more are intermediate. These intermediate earthquakes form an arc (Fig. 5) that presumably delineates the position of the subduction zone cited above, coinciding with the general Gibraltar topographic arc.

The distribution of the present active faults of the Betic Cordillera generally coincides with that of the seismicity, although to assign an earthquake to a determined fault is not easy, owing to the usual uncertainty regarding the location of the hypocentres and also to the lack of knowledge concerning the continuity of most of the faults at depth. IIn any case, a combination of seismic data and geologic observations is provide in the catalogue of the present active faults (García Mayordomo et al., 2012). A simplified scheme of these faults can be seen in Figure 6.

\section{Age, geodynamic conditions and related networks of fractures}

Age of formation of the different sets of faults and geodynamic conditions existing during these processes.

The first faults formed were the thrusts of the tectonic units, which occurred mainly during the Oligo- 


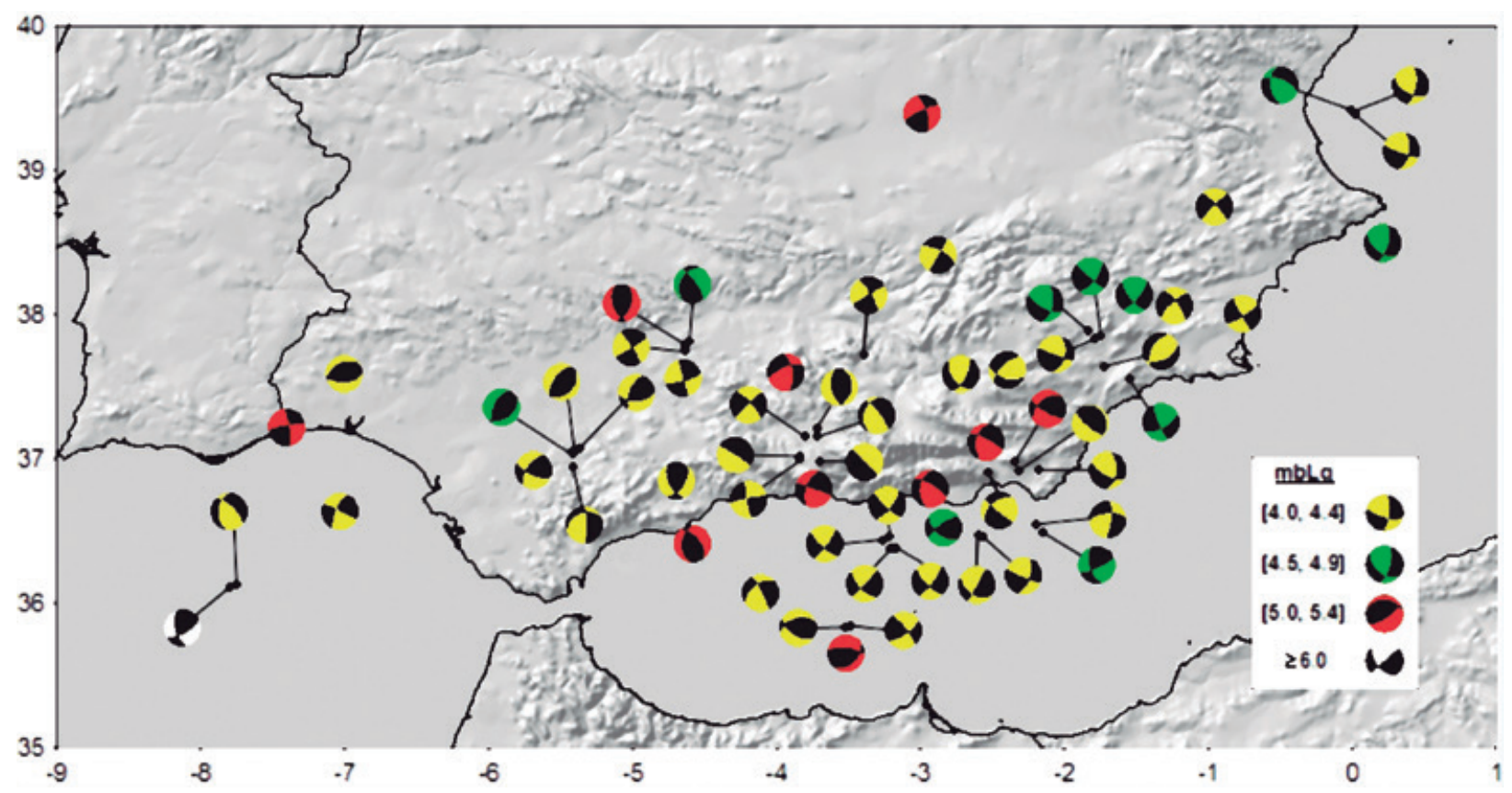

Figure 7. Focal mechanisms in the Betic Cordillera and neighbouring areas for earthquakes of magnitudes equal or superior to $4.0 \mathrm{mbLg}$, up to the year 2010. Taken from López-Casado and Henares Romero (2011).

Figura 7. Mecanismos focales en la Cordillera Bética y en áreas vecinas para terremotos de magnitudes iguales o superiores a 4,0 mbLg. hasta el año 2010. Tomado de López-Casado y Henares Romero (2011).

cene in the Internal Zone and from the Burdigalian in the External Zone. During the formation of the thrusts of the Internal Zone the compression had an approximately N-S to NNW-SSE direction.

The $\mathrm{N} 60^{\circ} \mathrm{E}-\mathrm{S} 60^{\circ} \mathrm{W}$ to $\mathrm{E}-\mathrm{W}$ faults began to be formed during the westwards drift of the Internal Zone, that is to say, more or less during the Burdigalian. Then the contact between both zones was formed and immediately, when this contact was in great measure immobilized, the Cadiz-Alicante fault was formed (and its parallel) and also the E-W corridors situated within the Internal Zone. The Cadiz-Alicante fault contributed to facilitate the westward displacement of the Internal Zone (and part of the External one), whilst the E-W corridors also contributed, but facilitated the relative displacements of different parts of the Internal Zone which lost its internal continuity. At this time, owing to the opening of the Algero-Provençal basin, the local direction of compression was practically E-W (that is to say, an extension in the interior of the opening basin co-existed with a compression in the borders due to the collision of the Internal Zone with the External Zones in the Betics and the Rif).

When the westward compression diminished, the general previous N-S to NNW-SSE compression was reestablished, and the Eastern Betic Shear Zone was then formed together with the NNW-SSE to NW-SE faults. This direction of compression is compatible with a perpendicular extension, which continued to facilitate the pre-existing westward movements. Moreover, this compression, combined with an isostatic readjustment, caused a nearly general uplift. Due to these factors, many faults underwent different types of displacement, whether normal or strike-slip, or the two combined.

The observations of the focal mechanism of recent earthquakes in the Betics and in the Alboran Sea (Fig. 7) express these different movements, even at present. As can be seen, many of these earthquakes correspond to strike-slip fault displaced by an approximately NNW-SSE compression, but other types of movements exist, owing to the different orientations of the faults and the particular circumstances of every sector of the cordillera.

A consideration of the smaller faults and joints associated with the formation of great faults.

Owing to the numerous deformations undergone by the rocks of the Betic Cordillera, small fractures (faults and joints) are abundant. In each episode affecting the rocks (thrusts, normal and strike-slip 
faults), some networks of faults formed. This is visible particularly in the proximities of the main faults, in some places giving rise to broad deformation zones (>100 $\mathrm{m}$ thick).

In many other cases, the networks formed are independent of the proximities of the principal faults. This happens for instance in the Nevado-Filabride Complex where, under a $\sim \mathrm{N}-\mathrm{S}$ compression (combined with an orthogonal extension), simultaneously to the formation of the great E-W anticline of Sierra Nevada, two sets of vertical conjugated joints of $\mathrm{N} 30^{\circ} \mathrm{E}-\mathrm{S} 30^{\circ} \mathrm{W}$ and $\mathrm{N} 30^{\circ} \mathrm{W}-\mathrm{S} 30^{\circ} \mathrm{E}$ directions appeared. These sets were formed from the end of the middle Miocene and the deeper joints were filled by quartz, albite, siderite, and other minerals, indicating the presence of hydrothermal fluids, whilst the more superficial joints do not present these fillings.

Well-defined sets of joints are also present in the Alpujarride Complex, also combined with small faults. These partially control the river network. Considered as a whole, these joints and small faults are "penetrative" structures (in this case the word penetrative is not used as a foliation or schistosity which affects all the rock, but rather refers to the fact that they are distributed throughout the entire volume of the rocks, more or less densely, although not at the small scale of a foliation).

Several studies have been made on fracturing in the Betic Cordillera, moreover those referring to the major faults. Sanz de Galdeano et al. (1984) studied the fractures of the SW area of Sierra Nevada, including areas of the Nevado-Filabride and Alpujarride Complexes and also Neogene sediments. They form well-defined sets of faults clearly attributable to those cited above.

Southward of this area, in the Alpujarride Complex (in the area of the village of Albuñol, near the coast), Sanz de Galdeano et al. (1985a) studied the distribution of small fractures visible in the field and in aerial images. They are more or less homogeneously distributed. Figure 8 corresponds to that article, which shows the abundance of these fractures and also their arrangement in several sets "penetratively" arrayed within the mass of the rocks. Most of the rocks in this area correspond to metapelites (phyllites and schists) but also to marble.

Many marble and limestone formations in the Betic Cordillera usually present sets of abundant fractures (joints and small faults) (Almécija et al., 1996) created under the same dynamic conditions forming the folds. In these cases, sets of conjugated fractures appear at angles of approximately $60^{\circ}$ from the axial direction of the folds. However, when the process of the folding has been complex, varying the orientation of the

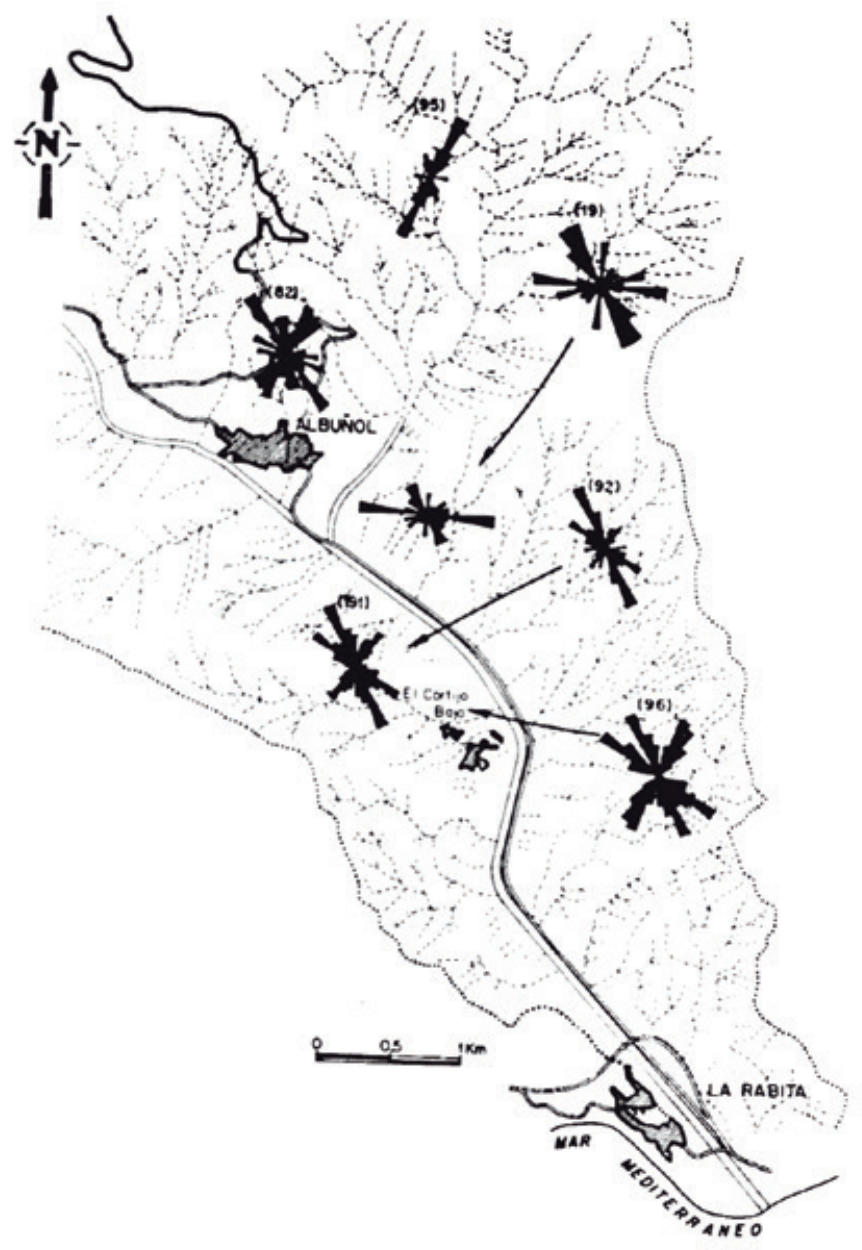

Figure 8. Fracture diagrams in several sectors of the Albuñol area. The numbers in brackets indicate the measurements taken in each sector. Taken from Sanz de Galdeano et al. (1985a).

Figura 8. Diagramas de fracturas en varios sectores del área de Albuñol. Los números entre paréntesis indican las medidas tomadas en cada sector. Tomado de Sanz de Galdeano et al. (1985a).

stress and the conditions of $\mathrm{P}$ and $\mathrm{T}$, the number of the sets of joints and small faults is great and not easy to interpret.

The dolomitic marble of the Alpujarride Complex has zones of intense breakage, forming "kakirites". Their origin, still controversial, probably depends on a great pressure of fluids.

In the Betic Cordillera the possible relations between the directions of karstification and those of thermalism have also been analyzed (Benavente and Sanz de Galdeano, 1985). The results indicate that the thermal springs are strongly controlled by the main sets of faults of the Cordillera. In particular, the set of faults of NW-SE to NNW-SSE strike, whilst those of $N 70^{\circ}-100^{\circ} \mathrm{E}$ strike have a minor control, with the exception of the points where these faults and those of NW-SE strike intersect. 


\section{Conclusions}

In the Betic Cordillera, aside from the thrust surfaces forming the different tectonic units, there are major sets of faults that are vertical or high angle. The thrusts were formed earlier, generally during the Oligocene in the Internal Zone, within a more or less N-S compression.

Later, in the Burdigalian, the Internal Zone was pushed westwards and, in this drift process, obliquely collided with the External Zone, which underwent a major structuring. This resulted from dextral $\mathrm{N} 60^{\circ} \mathrm{E}-$ $\mathrm{S} 60^{\circ} \mathrm{W}$ to $\mathrm{E}-\mathrm{W}$ faults, which also facilitated the drift. This process occurred under an approximately E-W compression, owing to the opening of the Algero-Provençal basin extending to the west in the Alboran Sea.

When this process lost intensity, from the middle Miocene, two sets of faults were then formed, with NNE-SSW and NNW-SSE to NW-SE strikes. The first makes up the important sinistral Eastern Shear Zone, and the second, conjugated with the first, is dextral and locally normal in character. These were formed under $\sim \mathrm{N}$-S compression, coexisting with an orthogonal extension.

These different sets of faults are represented not only by the above-mentioned major faults. On the contrary, a great number of fractures, faults and joints, are present in the rocks, and have very different sizes and a quasi-penetrative nature. These profuse fractures had the same tectonic control as the major faults. However, when the different deformation processes were superposed, the first fractures were rotated and cut off, making the control of the formation of these fractures difficult.

\section{Acknowledgements}

This work is a contribution of the project DAMAGE (AEI/FEDER CGL2016-80687-R) of DGICYT, and the research group RMN-370 of the Junta de Andalucía.

\section{References}

Aldaya, F., García Dueñas, V. and Navarro Vila, F. 1979. Los Mantos Alpujárrides del tercio central de las Cordilleras Béticas. Ensayo de correlación tectónica de los Alpujárrides. Acta Geològica Hispànica. Homenatge a Lluis Solé i Sabarís, 14, 154-166.

Almécija C., Benavente J. and Sanz de Galdeano C. 1996. Direcciones de drenaje en la vertiente sur de Sierra Almijara (Málaga). Influencia de la fracturación. Bol. Geol. y Min. 107-1, 69-74.
Augier, R., Agard, P., Monié, P., Jolivet, L., Robin, C. and Booth-Rea, G. 2005. Exhumation, doming and slab retreat in the Betic Cordillera (SE Spain): in situ ${ }^{40} \mathrm{Ar} /{ }^{39} / \mathrm{Ar}$ and P-T-d-t path for the Nevado-Filabride Complex. Journal of Metamorphic Geology, 23, 357-381.

Benavente J. and Sanz de Galdeano C. 1985. Relación entre las direcciones de karstificación y el termalismo con la fracturación de las Cordilleras Béticas. Estudios Geológicos, 41, 177188.

Boillot, G., Montadert, L., Lemoine, M. and Biju-Duval, B. 1984. Les marges continentales actuelles et fossiles autour de la France. Masson, Paris, 342 p.

Bousquet, J. C. 1979. Strike-slip faults in southeastern Spain. Tectonophysics, 52, 277-286.

Durand-Delga, M. and Fontboté, J.M. 1980. Le cadre structural de la Méditerranée occidentale. 26 Congrès. Géol. Intern., Paris. Les Chaînes alpines issues de la Téthys. Mém. B.R.G.M., 115, 67-85.

Foucault, A. 1974. Travaux et titres scientifiques et universitaires. Paris, $36 \mathrm{p}$.

Galindo-Zaldívar, J. 1993. Geometría de las deformaciones neógenas en Sierra Nevada (Cordilleras Béticas). Thesis Univ. Granada. Monografía Tierras del Sur, 249 p.

García-Mayordomo, J., Insua-Arévalo, J. M., Martínez-Díaz, J. J., Jiménez-Díaz, A., Martín-Banda, R., Martín-Alfageme, S., Álvarez-Gómez, J. A., Rodríguez-Peces, M., PérezLópez, R., Rodríguez-Pascua, M. A., Masana, E., Perea, H., Martín-González, F., Giner-Robles, J., Nemser, E. S., Cabral, J., Sanz de Galdeano, C., Peláez, J. A., García-Tortosa, F., Grácia, E., Bartolomé, R., Gonzalez, Á., Azañón, J. M., Alfaro, P., Moreno, X., Ferrero-Vega, A., Dias, R., Martínez, S., Gutiérrez, F., Ortuño, M., Booth-Rea, G., Giaconia, F., Martínez- Martínez, J. M., Villegas, I., Lo Lacono, C., Pérez- Peña, V., Martín- González, F., Brum de Silveira, A., García-Meléndez, E., Lafuente, P., Simón, J. L., Arlegui, L. E., Liesa, C. L., Bach, J. and Linares, R. 2012. The Quaternary active faults database of Iberia (QAFI v.2.0). Journal of Iberian Geology, 38, 1, 285-302. DOI: http://doi.org/10.5209/rev_JIGE.2012.v38.n1.39219

Hernández, J., de Larouzière, F.D., Bolze, J. and Bordet, P. 1987. Le magmatisme néogene bético-rifain et le couloir de décrochement "trans-Alboran». Bulletin de la Societé géologique de France, 3, 257-267.

Larouzière, F.D. de, Bolze, J., Bordet, P., Hernandez, J., Montenat, Ch. and Ott d'Estevou, Ph. 1988. The Betic segment of the lithosperic Trans-Alboran shear zone during the Late Miocene. Tectonophysics, 152, 41-52.

López Casado, C. and Henares Romero, J. 2011. Rasgos sísmicos generales y estado de esfuerzos de la Cordillera Bética. In Fallas activas de la Cordillera Bética. Una aproximación a partir de la información tectónica y sísmica. Univ. Granada, Sanz de Galdeano and Peláez (Eds), 31-67.

Martínez-Díaz, J. J. 2002. Stress field variation related to 
fault interaction in a reverse oblique-slip fault: the Alhama de Murcia fault, Betic Cordillera, Spain. Tectonophysics, 356, 1/3, 291-305.

Martínez Martínez J.M. 2006. Lateral interaction between metamorphic core complex and less-extended, tilt block domains: the Alpujarras strike-slip transfer fault zone (Betics, SE Spain). Journal of Structural Geology, 28, 602-620.

Martínez Solares, J. M. and Mezcua, J. 2002. Catálogo sísmico de la Península Ibérica (880 a. C.-1900). Instituto Geográfico Nacional.

Mauffret, A., Maldonado, A. and Campillo A.C. 1992. Tectonic framework of the Eastern Alboran and western Algerian basins, western Mediterranean. Geo-Marine Letters, 12, 2/3, 104-110.

Mezcua, J. and Martínez Solares, J. M. 1983. Sismicidad del área ibero mogrebí. Publicación $n^{\circ} 203$. Instituto Geográfico Nacional, 300 p.

Montenat, Ch., Ott d'Estevou, Ph. and Masse, P. 1987. Tectonic sedimentary characters of the Betic Neogene basins evolving in a crustal transcurrent shear zone (SE Spain). Bull. Centres Rech. Explor. Prod. Elf Aquitaine, 11, 1-22.

Pedrera, A., Ruiz-Constán ,A., Galindo-Zaldívar, J., Chalouan, A., Sanz de Galdeano, C., Marín-Lechado, C., Ruano, P., Benmakhlouf, M., Akil, M., López-Garrido, A.C., Chabli, A., Ahmamou, M. and González-Castillo L. 2011. Is there an active subduction beneath the Gibraltar orogenic arc? Constraints from Pliocene to present-day stress field. Journal of Geodynamics, 52, 83-96.

Puga, E., Díaz de Federico, A. and Nieto, J.M. 2002. Tectonostratigraphic subdivision and petrological characterisation of the deepest complexes of the Betic zone: a review. Geodinamica Acta, 15, 23-43

Sanz de Galdeano, C. 1983. Los accidentes y fracturas principales de las Cordilleras Béticas. Estudios Geológicos, 39, 157-165.

Sanz de Galdeano, C. 1990a. Geologic evolution of the Betic Cordilleras in the Western Mediterranean, Miocene to the present. Tectonophysics, 172, 107-119.
Sanz de Galdeano, C. 1990b. La prolongación hacia el sur de las fosas y desgarres del Norte y Centro de Europa: Una propuesta de Interpretación. Rev. Soc. Geol. España, 3, (1-2), 231-241.

Sanz de Galdeano, C. 2008. The Cádiz-Alicante Fault: an important discontinuity in the Betic Cordillera. Rev. de la Soc. Geológica de España, 20, 49-58.

Sanz de Galdeano, C. and Alfaro, P. 2004. Tectonic significance of the present relief of the Betic Cordillera. Geomorphology, 63, 178-190.

Sanz de Galdeano, C., Estévez, A., López Garrido, A.C. and Rodríguez Fernández, J. 1984. La fracturación tardía al SW de Sierra Nevada (terminación occidental del Corredor de las Alpujarras, Zona Bética). Estudios Geológicos, 40, 183191.

Sanz de Galdeano, C., Fernández Rubio, R. and Fernández Lorca, S. 1985a. Fracturación y fotointerpretación en el sector de Albuñol La Rábita (Conjunto Alpujárride, Cordilleras Béticas). Bol. Geol. Min., 96, 39.

Sanz de Galdeano, C. and López Garrido, A.C. 2016. The nevado-filábride complex in the western part of Sierra de los Filabres (Betic Internal Zone), structure and lithologic succession. Boletín Geológico y Minero, 127 (4): 823-836 ISSN: 0366-0176 DOI: 10.21701/bolgeomin.127.4.005

Sanz de Galdeano, C. and Peláez, J.A. (Eds.). 2011. Fallas activas de la Cordillera Bética. Una aproximación a partir de la información tectónica y sísmica. Editorial Universidad de Granada, 287 pp. I.S.B.N.: 978-84-338-5195-6. Ebook-9788433852410.html

Sanz de Galdeano, C., Rodríguez Fernández, J. and López Garrido, A.C. 1985b. A strike-slip fault corridor within the Alpujarra Mountains (Betic Cordilleras, Spain). Geol. Rundschau. 74, 3, 641655

Vera, J.A. 2001. Evolution of the South Iberian Continental Margin. In. P.A. Ziegler, W. Cavazza, A.H.F. Robertson \& S. Crasquin-Soleau (eds), Peri-Tethys Memoir 6: Peri-Tethyan Rift/Wrench Basins and Passive Margins. Mém. Mus. Natm. Hist. Nat., 186, 109-143. Paris.

Recibido: julio 2019

Revisado: noviembre 2019

Aceptado: enero 2020

Publicado: marzo 2021 